\title{
Challenges of Water Resources in Iraq
}

\author{
Mohamed Abd-El-Mooty, Rawya Kansoh, Ahmed Abdulhadi*
}

Irrigation and Hydraulics Department, Faculty of Engineering, Alexandria University, Alexandria, Egypt

\begin{abstract}
The current paper emphasizes on the study of the water resources of Iraq. Iraq is facing a dire water crisis due to the decrease in the quantities and degradation in the qualities of the water reaching its borders with the two rivers Tigris and Euphrates. The Euphrates and Tigris rivers provide more than $98 \%$ of Iraq's water demands for the various purposes. Degradation of these rivers has become a serious problem. Analysis of the previous studies is made and the available data are collected. Most of the studies reached an important conclusion, Iraq face serious water shortage problem. Analysis and Expectation of the population size, study of the existing agricultural use and expansion of the cultivated land are presented. The consumption of water withdrawals for the three purposes Agricultural, municipal, and industrial use are analyzed and presented in the paper. In addition, the Expectations of the share per capita are made for the Future until 2100, depending on the expectations of population size and amount of water supply. The water power is studied and suggestions for the new plant are made. Furthermore, some of the discharged fresh water to the Arabian Gulf represents a loss of fresh water. Suggestion to save this loss by constructing a new dam to separate between the fresh and salt water upstream Basra city is suggested. Some of the collected data is included in the paper.
\end{abstract}

Keywords: Water resources; Euphrates river; Tigris river; Iraq

\section{Introduction}

Water is required in the progressing of society and economics. In Iraq, there are two major rivers: Euphrates and Tigris. These rivers contributed a lot to the development of the Assyrian and Sumerian cultures where these nations were settled on the sides of the two rivers. These nations witnessed the building of the first hydraulic structures as dams and irrigation canal and the drafting of laws for organized use of river waters. Water has been and is still very important in the history of Iraq and its development away from political problems happening and wars. Iraq counts on the water of Tigris and Euphrates rivers, the source which comes mostly from outside country. Without a plan to preserve the long-term "strategic" water for Iraq, and prompt action, any gains in the security or economic atmosphere in Iraq may be lost. Shortage of water resources is one of the most important problems in the world due to increased demand and climate changes. Iraq was rich in its water resources relative to its neighbouring countries. Its richness continued to 1970s. After that year, the two neighbouring countries Syria and turkey began to build dams on Euphrates and Tigris Rivers. These dams caused a major shortage in the flow of the two Rivers and made severe deterioration in the quality of its water.

This paper includes the history of water resources and existing conditions. In addition, the analysis is made for the available data and suggestions for the proper use to get the optimum benefits. Study of the existing agricultural use is discussed and suggestions for expanding the cultivated land are presented. The water power is studied and suggestions for the new plant are made. Furthermore, some of the rivers water goes to the Arabian Gulf as a loss of fresh water. Constructing a new dam to separate between the fresh and salt water upstream Basra city is suggested. Instances of the existent data and their analysis are shown and the resulted are summed up.

\section{Review}

The site of Iraq is as shown in Figure 1. The geographic location of Iraq lies at $33^{\circ}$ North latitude and $44^{\circ}$ East longitude. The northsouth extents of Iraq's borders run from $37^{\circ} 21^{\prime} \mathrm{N}$ in the north region along its northern border with Turkey to $29^{\circ} 04^{\prime} \mathrm{N}$ along its southern border with Saudi Arabia. Iraq's east-west extent spans from $38^{\circ} 56^{\prime}$ in the Syrian Desert to $48^{\circ} 36^{\prime}$ in the vicinity of the Shatt al Arab. Iraq is a fairly compact country, as its geographic centre is relatively equidistant from its borders. Iraq is a southwest Asian country that that is surrounded by Syria and Jordan to the west, Turkey to the north, Iran to the east and by Saudi Arabia and Kuwait to the south. In Iraq, the only path to enter naval traffic is from Shatt $\mathrm{Al} \mathrm{Arab.} \mathrm{With} \mathrm{an} \mathrm{area} \mathrm{of}$ $437,065 \mathrm{~km}^{2}$, the country has high, rugged mountains along its border with Iran and Turkey. The highest point in Iraq is HAJI IBRAHIM along the Iran-Iraqi border at 3607 meters. And the lowest point is at Arabian Gulf with at $0 \mathrm{~m}$ [1].

The climate of Iraq is arid and dry, distinguished by hot summers and short cold winters. It is affected by the location of the country between the sub-tropical dryness of the Arabian Desert areas and the sub-tropical wetness of the Arabian Gulf. The average of hotness and coldness in Iraq is approximately higher than 48 degrees $C$ in July and August and below freezing in January. A majority of the rainfall happens from December through April and is more plentiful in the mountainous region and may reach $100 \mathrm{Cm}$ a year in some places [2]. In most of the areas, summers are warm to hot with mostly sunshine, but high moisture on the southern coastal areas of the Arabian Gulf. Daily Temperatures can be very hot; on some day's temperatures, can reach easily $45^{\circ} \mathrm{C}$ or more, especially in the Iraqi desert areas which cause a danger of heat attrition. Hot, dry desert winds can be very strong sometimes, and can cause violent sandstorms. Two different wind patterns are seen throughout Iraq during the summer months. The southern and east southern winds move between April and June and again from late September through November. The winds last up to several days at a time and bring dust storms and 50 miles per hour gale. June through September, the north-westerly shamal wind is present throughout the country, bringing dry air and a steady breeze that provides a slight cooling effect [3].

*Corresponding author: Ahmed Abdulhadi, Research Student, Irrigation and Hydraulics Department, Faculty of Engineering, Alexandria University, Alexandria, Egypt, Tel: 0115465050; E-mail: ahmed199018@yahoo.com

Received October 11, 2016; Accepted October 25, 2016; Published November 01,2016

Citation: Abd-El-Mooty M, Kansoh R, Abdulhadi A (2016) Challenges of Water Resources in Iraq. Hydrol Current Res 7: 260. doi: 10.4172/2157-7587.1000260

Copyright: (c) 2016 Abd-El-Mooty M, et al. This is an open-access article distributed under the terms of the Creative Commons Attribution License, which permits unrestricted use, distribution, and reproduction in any medium, provided the original author and source are credited. 


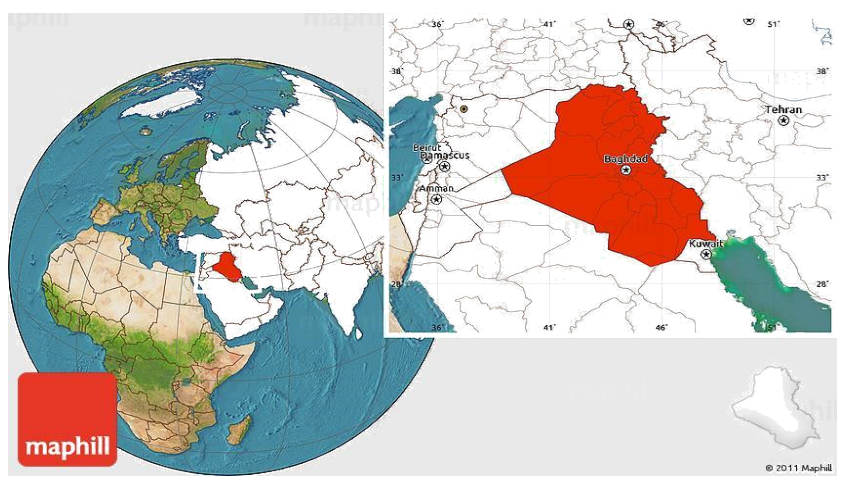

Figure 1: Location of Iraq in the world and region.

\section{Collection of Data}

Several major problems were encountered during the research. Of these, the most significant were the unavailability of data for the study. Those found in the government offices are mostly confidential and restricted. Thus, it is impossible to collect such data. However, the data obtained for this work are both important and substantial. With only minor limitations, they cover all aspects of the study. These data have been analysed and results of significance have been deduced.

\section{Surface water}

Tigris and Euphrates are the main water resources in Iraq and these two rivers stem from Turkey and join together in the south of Iraq to create Shatt Al-Arab which drains to the Arabian Gulf. Before the confluence, the Euphrates River stream about $1000 \mathrm{~km}$ and the Tigris for about $1300 \mathrm{~km}$ within the border of Iraq (Figure 2). These two rivers account for $98 \%$ of the Iraqi surface water [4]. The total of the annual flow of the Euphrates and Tigris River is about 80 to $84.2 \mathrm{BCM}, 65.7$ $\mathrm{BCM}$ comes from Turkey, 11.2 BCM from Iran, 6.8 BCM comes from Iraq, and $0.5 \mathrm{BCM}$ comes from Syria. This shows the controlling of Turkey on the water for both Euphrates and Tigris River [5].

Tigris River: Tigris River is the second largest river in the southwest, Asia. It rises in the south-eastern part of Turkey. Its name "Tigris" comes from Sumerian civilization, "Dijla" in the Arabic language, and "Dicle" in the Turkish language. The water shade of Tigris river includes 4 countries Turkey, Iraq, Iran, Syria. The total drainage area of the Tigris River is $235,000 \mathrm{~km}^{2}$ distributed between Turkey (17\%), Syria (2\%), Iran (29\%) and Iraq (52\%) [6]. The total length of the river is about $1718 \mathrm{~km}$. Tigris River mean discharge at Mosul city prior to 1984 was $701 \mathrm{~m}^{3} / \mathrm{S}$ and dropped to $596 \mathrm{~m}^{3} / \mathrm{S}$ afterward. This shows a $15 \%$ decrease of the river flux. Figure 3 reveals the variations in the discharges of the Tigris River at Kut city on the left bank of the Tigris River, about $160 \mathrm{~km}$ southeast of Baghdad city for the period 1932 to 2005. Then join the Euphrates River in Basra city [2,6-8].

Euphrates River: The length of the river is about $2940 \mathrm{~km}$. The River rises in the high mountains of southern Turkey. It runs 1178 $\mathrm{km}$ in Turkey and then reaches the border of Syria where it courses $604 \mathrm{~km}$ to reach the Iraqi border [2]. The length of the Euphrates river inside Iraq is about $1160 \mathrm{~km}$. The total catchment area of the river is $444,000 \mathrm{~km}^{2}$, and the distribution of this area in the riparian countries are $28 \%, 17 \%, 40 \%$ and $15 \%$ in Turkey, Syria, Iraq and Saudi Arabia, respectively. It raises east the Anatolian plateau between Wan lake and the. The Euphrates enters Iraq and runs 220 kilometres to reach Hit city; the minimum and maximum recorded discharges at Hit station are $55 \mathrm{~m}^{3} / \mathrm{s}$ on $5 / 9 / 1973$ and $7460 \mathrm{~m}^{3} / \mathrm{s}$ on 13/5/1969. Figure 4 shows the change in discharges of the river at Hit city for period 1932 to 1997. Then, $63 \mathrm{~km}$ to the south of Hit city Euphrates River reach to Ramadi city with a width reaching $250 \mathrm{~m}$. In Ramadi city, there is a barrage was constructed on the river to supply Warra stream with water, this barrage called Ramadi barrage [2]. This discharge supplies Habaniya Lake with excess water from the Euphrates over the flood time. After that, the river combines with Tigris river in Basra city (Figure 2).

Shatt AL- Arab River: Shatt Al- Arab River is formed by joining the two rivers Euphrates and Tigris near Qurnah city in southern Iraq. The river width is about 250-300 near the Euphrates-Tigris confluence to almost $700 \mathrm{~m}$ near the city of Basra and more than $800 \mathrm{~m}$ as it approaches the river outlet. The total length of the shaat al-Arab is about $192 \mathrm{~km}$ [9]. There are more tributaries join the Shatt al- Arab river most importantly the Karkheh and the Karun Rivers [10]. The potential long-term mean annual discharge is $73.6 \mathrm{BCM}$, this volume is calculated as the sum of the long-term mean annual flow estimates of the four Shatt al Arab tributaries, with the following values: the Karun contributes 24.5 BCM (measured at Ahvaz gauging station), the Karkheh 5.8 BCM, the Euphrates 17.6 BCM (measured at Hindiyah) and the Tigris $25.7 \mathrm{BCM}$ (measured at Kut) [9]. There is limited information on water resource development projects in the Shatt-alArab region. However, in 2011 the Iraqi Ministry of Water Resources announced plans to construct a $129 \mathrm{~km}$ channel to divert water from the Shatt al-Arab River for irrigation purposes. The irrigation channel will transfer about $0.95 \mathrm{BCM} /$ year of water for use on agricultural land in Basra Governorate [11].

\section{Groundwater}

The use of ground water in Iraq is low. It ranges between $2 \%$ to $9 \%$ of water in Iraq. Ministry of water resources has divided Iraq into ten groundwater zones and is carrying out hydrogeological surveys for each of them. In the desert blocks, surveys have been largely completed, concluding that more wells could be sunk in specific aquifers [12]. Thousands of wells were excavated in different parts of Iraq for various purposes, especially in the 1980s where a large number of wells were drilled for agricultural purposes. The total number of wells excavated up to 1990 reached 8752 of which 1200 are used for agricultural purposes. These wells were excavated by the government. The number of wells excavated by the private sector reached 400 . After the war between Iraq and Kuwait in 1990, no records are available about the number of wells excavated. It is believed that a large number of wells excavated during the 1990s where the government encouraged the private sector to raise agricultural productivity because UN sanction [2]. The total amount of ground water per year is about 1.2 BCM.

\section{Agricultural land}

The land area of Iraq is $437,065 \mathrm{~km}^{2}$, with a population of 35.7 million in 2015. It is estimated that 11.48 million hectares, or $26 \%$ of the total area of the country, are cultivable. The mean of the total area that used for agricultural is about 9060123 ha (9.06 million ha), which is almost $79 \%$ of the cultivable area. However, this means that the percentage of the agricultural area is about $20.7 \%$ from the whole area of the county. Figure 5 demonstrates the agricultural area of the country for the period that started from 1961s and extends to 2013. It can be clearly seen that the area of agriculture is not stable and changed, where it was 8.8 million ha in 1961, then it was slightly increased to reach 9.53 million ha in 1988. There was dramatic decrease in the agricultural area happened in 2000 and 2010 where the agricultural area was recorded 8.3 and 7.85 million ha respectively. In the year 2013, the area of the 


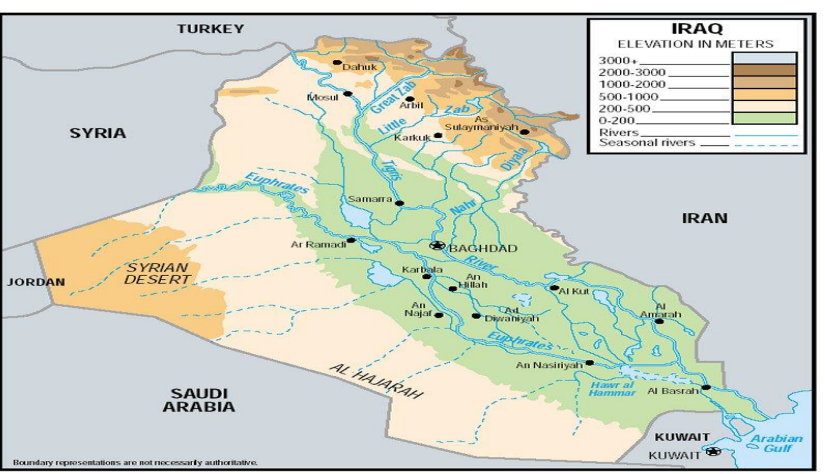

Figure 2: Map of Tigris and Euphrates Rivers.

Figure . Annual discharges of Tigris River in BCM at Kut city for period 1932 to 2005

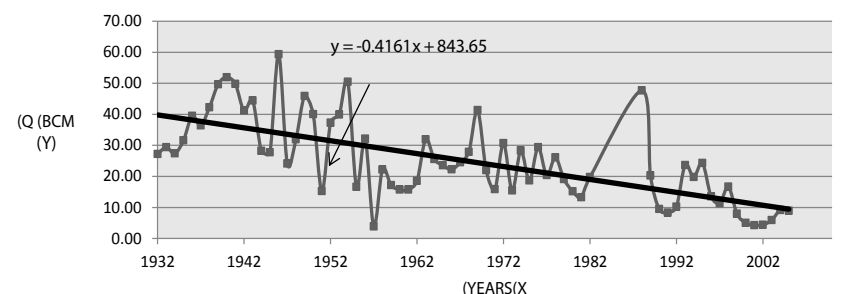

Figure 3: Annual discharges of Tigris River in BCM at Kut city for period 1932 to 2005 .

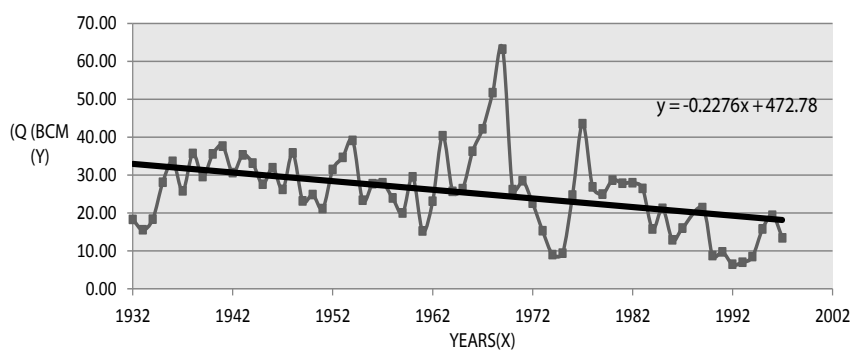

Figure 4: Annual discharges of Euphrates River in BCM at Hit city for period 1932 to 1997.

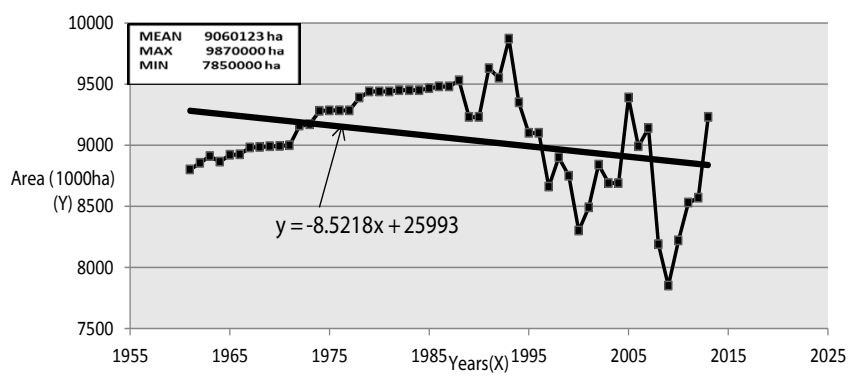

Figure 5: Agricultural area of Iraq (1000 ha) for period between 1961s to 2013

agricultural land returns to increase again to reach 9.23 million ha. The year of 1993 witnessed the maximum recorded area it was 9.87 million ha. In addition, the mean Arable land area and permanent crops are about 5.05 million ha which represented $11.5 \%$ of total land and this percentage is small relatively. More than half $(53 \%)$ of the arable land is rained, nearly all of it in the northern uplands; however, most of the agricultural production comes from the more intensively cultivated areas of the irrigated plains. But, because of soil salinity, fallow practices, and the precarious political situation, it is estimated that only 3 to 5 million ha are actually planted annually. In 1993, the area actually cultivated was estimated at about 3.73 million ha, of which 3.46 million ha consisted of annual crops and 0.27 million ha consisted of permanent crops. Figure 6 illustrates the total arable land area and permanent crops for the period 1961 to 2013. From the figure, we can notice that the maximum area was recorded in 1993 and it was about 5.87 million ha. The mean irrigated area by surface water are considered to be 2.84 million ha. $4 \%$ of this area ( 0.12 million ha) are irrigated by Shatt Al-Arab basin, $66 \%$ of this area ( 1.87 million ha) are irrigated by Tigris river basin, and 30\% ( 0.852 million ha) are irrigated by Euphrates river basin. In 1990, about 220,000 ha were irrigated by groundwater.

\section{Mathematical Analysis}

From the collected data, a mathematical analysis is prepared to calculate the Total Annual Water Volume (TAWV) which include the annual volume discharge from Tigris river $(\mathrm{T})$, annual volume discharge from Euphrates river (E), and annual volume of water from Rainfall (R). This is made according to the regression analysis and statistical procedure.

Regression analysis: Regression analysis is a procedure for fitting an equation to set of data. Specifically, given a set of measurements of two random variables, $\mathrm{Y}$ and $\mathrm{X}$, regression provides a means for finding the values of the coefficients, $\mathrm{b} 0$, and $\mathrm{b} 1$ for the straight line $\left(\mathrm{Y}=\mathrm{b} 0+\mathrm{b} 1^{*}\right.$ $\mathrm{X})$ that best fits the data. Statistical optimizations have three elements: an objective function, a model, and a sample of $\mathrm{X}$ and $\mathrm{Y}$ values. The function to be optimized is called the objective function, which is an explicit mathematical function that describes what is considered the optimal solution. The mathematical model relates a random variable, called the criterion or dependent variable, to the unknowns and the predictor variables $\mathrm{X}$, which is sometimes called the independent variable. The predictor's variables usually have a causal relationship with the creation variables. The third element of statistical optimization is a data set. The data set consists of measured values of the criterion variables and corresponding values of the predictor variable (Statistical Methods in Hydrology).

The most frequently used linear model relates a criterion variable $Y$ to a single predictor variable $\mathrm{X}$ by the equation

$$
\mathrm{Y}^{\wedge}=\mathrm{b} 0-\mathrm{b} 1 . \mathrm{x}
$$

b0 is the intercept coefficient

b1 is the slop coefficient.

Both $\mathrm{b} 0$ and $\mathrm{b} 1$ are often called regression coefficients because they are obtained from the regression analysis.

The linear multivariate model relates a criterion variable to two or more predictor variables.

$\mathrm{y}^{\wedge}=\mathrm{b} 0+\mathrm{b} 1 . \mathrm{x} 1+\mathrm{b} 2 \cdot \mathrm{x} 2+\ldots \ldots \ldots+\mathrm{bp} \cdot \mathrm{xp}$

Where $\mathrm{p}$ is the number of predictor variables.

\section{Solution procedure}

There are three predictor variables and one objective function:

a) Volume of water discharge of the Euphrates River in billion 


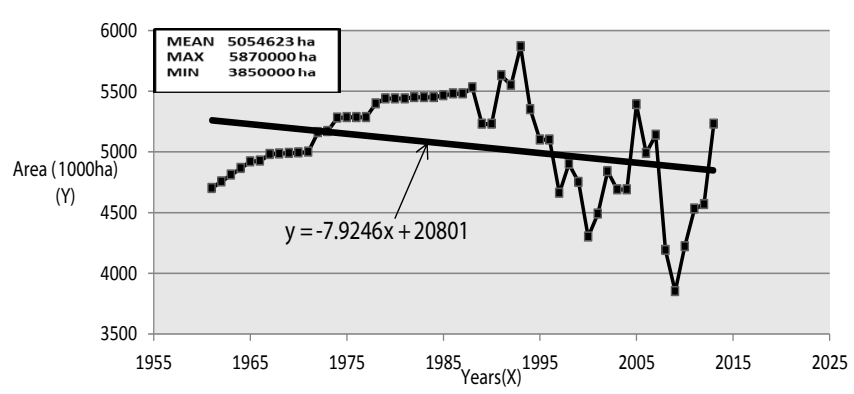

Figure 6: Arable land and permanent crops (1000 ha) for the period 1961s to 2013.
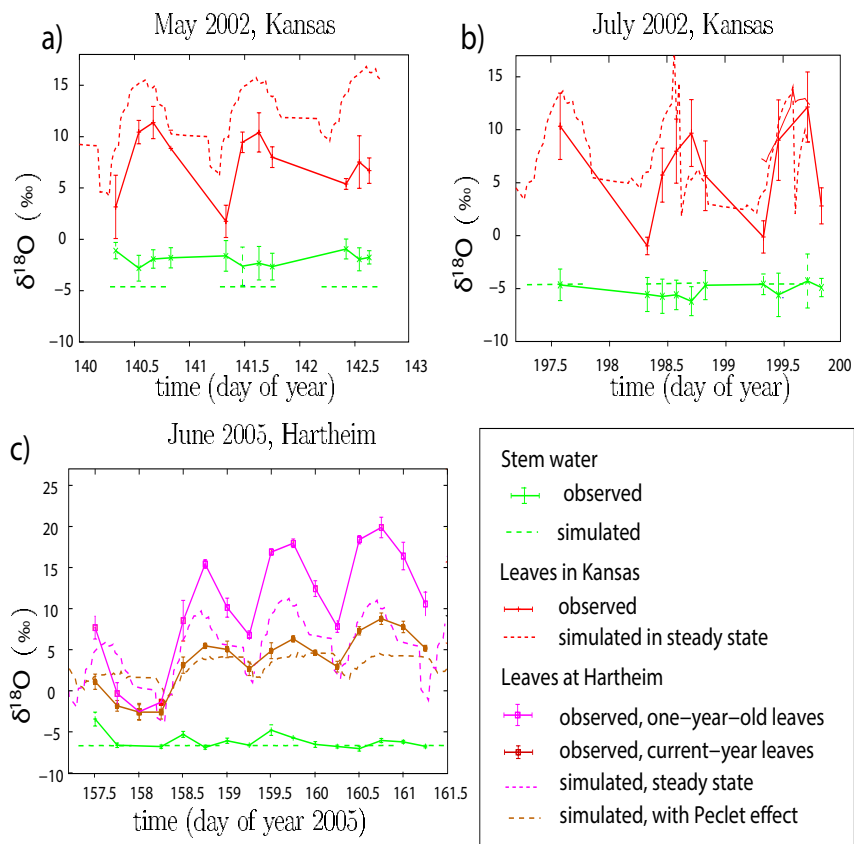

Figure 7: Total population of Iraq from 1960s to 2011s.

cubic meters (E), which is represented by $\mathrm{x} 1$.

b) Volume of water discharge of the Tigris River in billion cubic meters $(\mathrm{T})$, which is represented by $\mathrm{x} 2$.

c) Volume of rainfall for the whole area of Iraq in billion cubic meters (R), which is represented by $\mathrm{x} 3$.

d) Total annual water volume (TAWV) which is represented as the objective function $(y)$.

So, the equation of the total annual water volume can be written as:

$$
\mathrm{TAWV}^{\wedge}=\mathrm{b} 0+\mathrm{b} 1 . \mathrm{E}+\mathrm{b} 2 . \mathrm{T}+\mathrm{b} 3 . \mathrm{R}
$$

$$
\text { Or } \mathrm{y}^{\wedge}=\mathrm{b} 0+\mathrm{b} 1 . \mathrm{x} 1+\mathrm{b} 2 . \mathrm{x} 2+\mathrm{b} 3 . \mathrm{x} 3
$$

The values of b1, b2, b3, and b0 can be computed by using the principle of least squares, which is sometime referred to as regression analysis. The principle least squares are a process of obtaining best estimates of the coefficients and are referred to as a regression model.

$$
\mathrm{ei}=\mathrm{y}^{\wedge} \mathrm{i}-\mathrm{yi}
$$

where: $\mathrm{Y}^{\wedge} \mathrm{i}$ is the predicted value of the criterion variable, $\mathrm{Yi}$ is the measured value of $y$

$$
\mathrm{i}=1,2, \ldots \ldots ., \mathrm{p}
$$

and ei is the error or residual as the difference between the predicted and measured values of the criterion variable

The objective function for the principle of least squares is to minimize the sum of the squares of the errors.

$$
\begin{aligned}
& F=\min \sum_{i=1}^{n} e i^{2}=\min \sum_{i=1}^{n}\left(\mathrm{yi}^{\wedge}-\mathrm{yi}\right)^{2} \\
& F=\min \sum_{i=1}^{n}\left(\mathrm{~b}_{\mathrm{o}}+\mathrm{b} 1 . \mathrm{xi} 1+\mathrm{b} 2 \cdot \mathrm{xi} 2+\mathrm{b} 3 . \mathrm{xi} 3-\mathrm{yi}\right)^{2}
\end{aligned}
$$

Where, $\mathrm{n}$ is the number of observations on the criterion variable. Period one and period two are chosen as a sample for the three variables, which means that the number of observation (n) equals to 50 stated from 1932s to 1981 s.

Carrying the statistical procedures, the three parameters are obtained. The Total Annual Water Volume (TAWV), average annual volume of the Tigris River (T), average annual volume of Euphrates River (E), and average annual volume of the rainfall are found as follows:

$$
50 \cdot \mathrm{b}_{0}+1437 \cdot 10 \cdot \mathrm{b} 1+1463 \cdot 6 \cdot \mathrm{b} 2+360 \cdot 11 \cdot \mathrm{b} 3=3260
$$

$1437.10 \cdot \mathrm{b}_{0}+45978.32 . \mathrm{b} 1+44232.92 . \mathrm{b} 2+10542.66 \cdot \mathrm{b3}=100753.90(9)$

1463.60. $\mathrm{b}_{0}+44232.92 . \mathrm{b} 1+50013.73 . \mathrm{b} 2+10846.6 . \mathrm{b} 3=105093.28(10)$

$360.11 . b_{0}+10542 . b 1+10846.63 . b 2+2669.6 . b 3=24058.89$

Solving equations $8,9,10$, and 1 the three parameters are obtained and the final equation joining the different variables is:

$$
\text { TAWV }=-0.5914+1.0021 . \mathrm{E}+0.997 . \mathrm{T}+1.0727 . \mathrm{R}
$$

Using equation (12), the total flow of water in Iraq is calculated and analyzed as shown in the following section.

\section{Analysis and Results}

\section{Population}

The population of Iraq in the 1980s approximately was 13.7 million capita, and increased to 31 million in 2010s, and it is expected that the population will keep on increasing to reach 71.3 million in 2050 . The population growth in Iraq is considered very high. The rate is about 3.6\%; Figure 7 shows the population growth of Iraq for the period 1960 to 2011 . However, in 1961 population size was 7.47 million and in 1995 the population was 20.2 million reaches 32 million in 2013. Population density ranges from 5 to 170 inhabitants $/ \mathrm{km}^{2}$ in western and central part of the country [13].

According to the Food and Agriculture organization of the united Nation, country fact sheet, Iraq [14], the total population of Iraq is about 34.769 million in 2014, and the population density is about 79.88 inhabitants $/ \mathrm{km}^{2}$. The expected population size is made until 2100 depending on the expected population growth. The population size of Iraq is expected to be 44.35 million in 2025 where the population growth is expected to be 2.4 percent. While in 2075 and 2100 the population size is expected to be 83.9 and 178.5 million respectively as the population growth expected to be 1.95 percent in 2075 and 3.2 percent in 2100. Table 1 and Figure 8 show these values.

\section{Water demand}

In 1950 Iraq started to plan the building of the irrigation and flood control system. The purpose of this project was primary to protect Baghdad and other cities from the flood. And the first irrigation project 
was Dokan dam built in 1959 on the Tigris River [15,16]. Iraq was rich in its water resources relative to its neighbouring countries. Its richness continued to 1970s. After this year, the two neighbouring countries Syria and turkey began to build dams on Euphrates and Tigris Rivers. These dams caused a major shortage in the flow of the Euphrates River and also make severe deterioration in the quality of its water. Tigris and Euphrates are the main water resources in Iraq and these two rivers stem from Turkey and join together in the south of Iraq (in the Basra province) forming Shatt Al-Arab which drains to the Arabian Gulf. The Turkish government started to build a big project in the southeastern Anatolia (GAP) in 1977. This project consists of 22 multipurpose dams and 19 hydraulic power plants with a total storage capacity of $100 \mathrm{~km}^{3}$. This amount equal about three times more than total flow to Iraq and Syrian [6]. The total supply of water of the Tigris and the Euphrates in 2004 Table 2 was $64.9 \mathrm{BCM}$, which decreases in 2005 to $54.6 \mathrm{BCM}$ and to a mean of $24.2 \mathrm{BCM}$ per hydrological year over the period of 2007-2008, then falling to 15.7 BCM by April of the hydrological year 2008-2009. This mean that the decline in the water supply of the rivers amounted to $49.2 \mathrm{BCM}$, a decline of $75.8 \%$ compared to 2004 . Because of the scarcity of water in the Euphrates River in 2009, 5.4 BCM of water stored in the Haditha Dam has been transferred to the river in order to meet some of the water requirements of agricultural activities in the basin [16]. The reduction in the amount of water flowing into Tigris and the Euphrates is due not only to the lack of precipitation but also to supervision by the headwaters states of the two rivers Syria, Turkey, and Iran of the amount of water inflow into Iraq. Turkey has constructed a set of dams and reservoirs on the Tigris and Euphrates, which includes 13 projects for irrigation and power generation. The overall storage capacity of these dams are $138 \mathrm{BCM}$ of water from the two rivers Tigris and Euphrates. Syria has established dams on the Euphrates River with a storage capacity of $14.1 \mathrm{BCM}$, and these projects have led to a decline in the supply of water to Iraq [16]. The irrigation method used in Iraq is flooding the land with water and this method has low efficiency (it's about $40 \%$ of the water applied) and caused more losses in the amount of water. However, an analysis of data compiled prior to 2000 . The mean volume of water use in agricultural for the period 1975 to 2000 is 42.72 BCM per year (Table 3) which represents $91.2 \%$ from the total water available. The agricultural water withdrawals per person as a mean are $2597.1 \mathrm{~m}^{3} /$ person/year for the same period (Figure 9).

The mean water withdrawals for the municipal use are $1.75 \mathrm{BCM}$ per year for the period 1975 to 2000. In 2000, the volume of water withdrawal is $4.3 \mathrm{BCM}$ (Table 4); this represents $6.51 \%$ from the total withdrawals. For water withdrawal by one person in 2000 equals 182.40 $\mathrm{m}^{3} /$ person/year as the total population was 23.57 million, while, the mean water withdrawal by one person for the period 1975 to 2000 equals to $91.77 \mathrm{~m}^{3} /$ person/year (Figure 10).

Calculating the domestic water used per capita is found to be 251.42 litre/person/day, these amounts of water is considered high and should be reduced to 150 litre/capita/ day.

The used water in industry for the period 1975-2000 is shown in Table 5. The used water for the industry in 2000 equals to $9.7 \mathrm{BCM}$ (Table 5) and the mean annual water withdrawals per person for the period 1975 to 2000 equals to $149.8 \mathrm{~m}^{3} /$ person/year (Figure 11). The withdrawal of water for the industry for the same period is $5.47 \%$ from the total withdrawals.

Figure 12 show the expectation of the stake start from 2015 to 2100 . It can be clearly seen that the amount of water for one person will decrease with the increase of population size. In 2075 the population

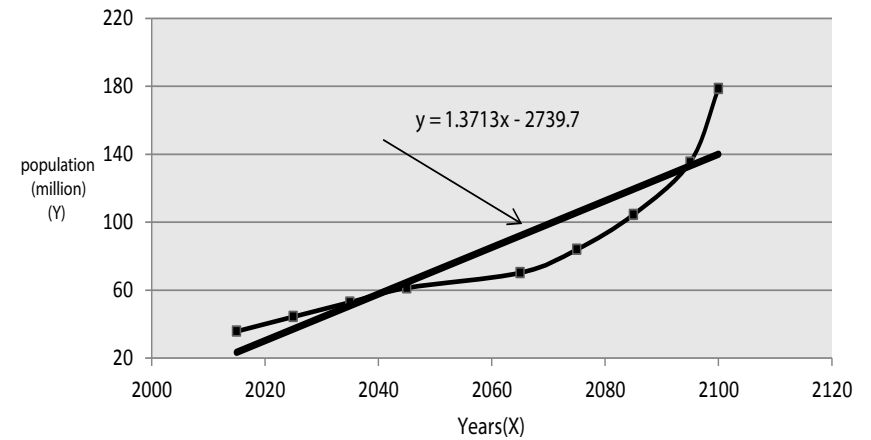

Figure 8: Expected population size of Iraq up to year 2100.

\begin{tabular}{|c|c|c|}
\hline Year & Population Growth (\%) & Population size \\
\hline 2015 & 2.89 & 35767000 \\
\hline 2025 & 2.4 & 44351080 \\
\hline 2035 & 1.92 & 52866487 \\
\hline 2045 & 1.6 & 61325125 \\
\hline 2065 & 1.45 & 70217269 \\
\hline 2075 & 1.95 & 83909636 \\
\hline 2085 & 2.45 & 104467497 \\
\hline 2095 & 2.95 & 135285408 \\
\hline 2100 & 3.2 & 178576738.8 \\
\hline
\end{tabular}

Table 1: Expected of population size and Population growth in Iraq to 2100.

\begin{tabular}{|c|c|c|c|}
\hline Years & Tigris & Euphrates & Total \\
\hline 2004 & 44.4 & 20.5 & 64.9 \\
\hline 2005 & 37 & 17.6 & 54.6 \\
\hline $2007-2008$ & 15.9 & 8.3 & 24.2 \\
\hline 2008-April 2009 & 10.7 & 5 & 15.7 \\
\hline
\end{tabular}

Table 2: The water supply of the Tigris and the Euphrates in Iraq (BCM) in the period from 2004 to April 2009 [17].

\begin{tabular}{|c|c|c|c|c|}
\hline Year & $\begin{array}{c}\text { Agricultural } \\
\text { water } \\
\text { Withdrawal }\left(10^{9}\right. \\
\left.\mathrm{m}^{3} / \text { year }\right)\end{array}$ & $\begin{array}{c}\text { Total } \\
\text { population }\end{array}$ & $\begin{array}{l}\text { Stake of one } \\
\text { person per } \\
\text { year } \mathrm{m}^{3} / \mathrm{p} / \\
\text { year }\end{array}$ & $\begin{array}{l}\text { Agricultural water } \\
\text { withdrawal as } \\
\% \text { of total water } \\
\text { withdrawal }\end{array}$ \\
\hline 1975 & 39.53 & 11684585 & 3383.09 & 97.46 \\
\hline 1980 & 39.77 & 13653358 & 2912.84 & 97.48 \\
\hline 1985 & 40 & 15576396 & 2567.99 & 97.51 \\
\hline 1990 & 39.38 & 17478455 & 2253.06 & 92.01 \\
\hline 1995 & 45.69 & 20217759 & 2259.89 & 83.99 \\
\hline 2000 & 52 & 23574751 & 2205.75 & 78.79 \\
\hline
\end{tabular}

Table 3: Agricultural water withdrawals for the period 1975 to 2000.

\begin{tabular}{|c|c|c|c|c|}
\hline Year & $\begin{array}{c}\text { Municipal water } \\
\text { withdrawal (109 } \\
\mathrm{m}^{3} / \text { year) }\end{array}$ & $\begin{array}{c}\text { Total } \\
\text { population }\end{array}$ & $\begin{array}{c}\text { Stake of one } \\
\text { person per year } \\
\mathrm{m}^{3} / \mathrm{p} / \text { year }\end{array}$ & $\begin{array}{l}\text { Municipal water } \\
\text { withdrawal as \% } \\
\text { of total withdrawal }\end{array}$ \\
\hline 1975 & 0.58 & 11684585 & 49.64 & 1.43 \\
\hline 1980 & 0.72 & 13653358 & 52.73 & 1.75 \\
\hline 1985 & 0.85 & 15576396 & 54.57 & 2.07 \\
\hline 1990 & 1.28 & 17478455 & 73.23 & 2.99 \\
\hline 1995 & 2.79 & 20217759 & 138 & 5.13 \\
\hline 2000 & 4.3 & 23574751 & 182.4 & 6.51 \\
\hline
\end{tabular}

Table 4: Municipal water withdrawals for the period 1975 to 2000. 


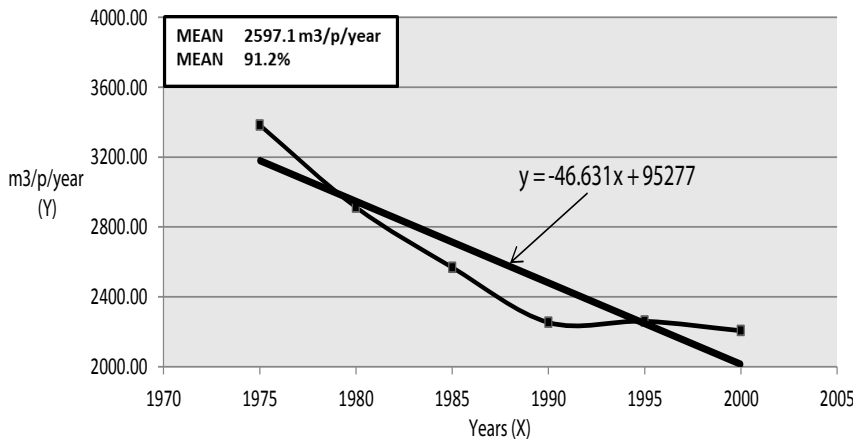

Figure 9: Agricultural water withdrawal (m³/person/year) for the period 1975 to 2000 .

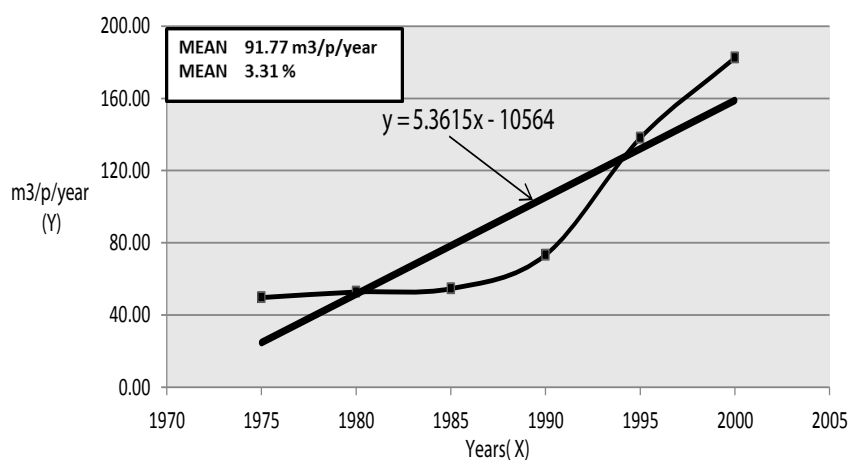

Figure 10: Municipal water withdrawal ( $\mathrm{m}^{3} /$ person/year) for the period 1975 to 2000 .

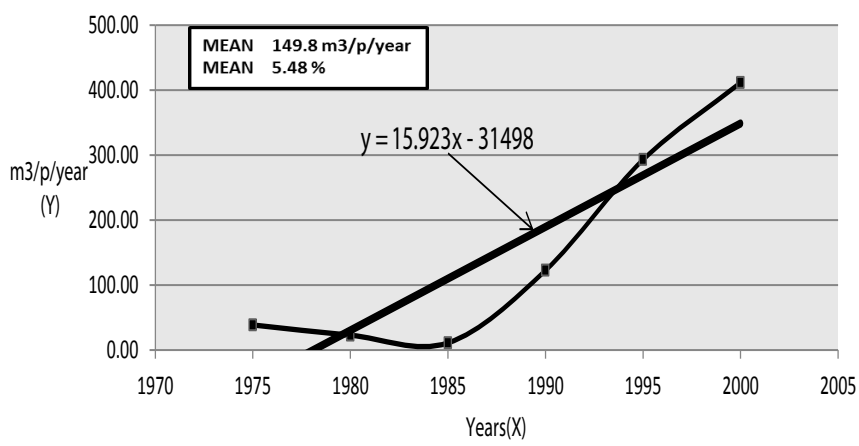

Figure 11: Industrial water withdrawal ( $\mathrm{m}^{3} /$ person/year) for the period 1975 to 2000.

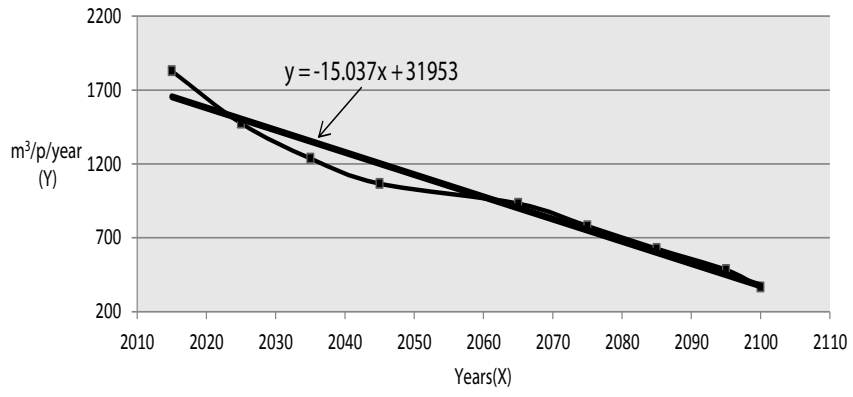

Figure 12: Expectation of population and stake of person in $\mathrm{m}^{3} / y e a r$ for the period 2015 s to 2100 . size will be 83.9 million and the stake of person will be $780 \mathrm{~m}^{3} /$ person/ year. These values will not remain constant and there will be a dramatic decrease in 2100 . However, in 2100 the population size will be 178.5 million and stake of person will be $366 \mathrm{~m}^{3} /$ person/ year (Table 6). The expectation calculated depended on the mean annual water volume equal to $65.53 \mathrm{BCM}$ per year which is calculated depending on 75 years of the available data of discharges for Euphrates and Tigris River and also rainfall volume which is equal to approximately 7 BCM.

\section{Water power}

Any hydraulic structures like dams, barrages or regulators should include power generation plant. Many dams were built in Iraq on the Tigris and Euphrates Rivers in order to give the ability to establish a hydro plant beside these dams. The concept of constructing dams in Iraq was originated in the initial half of the twentieth century. Mainly it was to guard Baghdad, the capital, and other major cities from flooding. The first big dam (Dokan) was built in 1959 on the Lesser Zab River. Subsequently, dams were constructing for irrigation and power generation objective. The Iraqi Government realized the process of building dams should be speeded up due the massive rise in water demand. The processes stopped in the 1990s due to the second Gulf war and UN sanctions. None of these dams were loaded to their maximum storage capacities during the twenty-first century because of the depletion of flow in the Euphrates and Tigris Rivers by the Turkish and Syrian dams. Declining flows in the Euphrates have affected hydropower production and reduced water required for irrigation. Currently, there are six small hydropower stations operating in Iraq (Table 7). Only one of the listed projects has a capacity below $10 \mathrm{MW}$ $[17,18]$. New hydropower plants should be built at any waterfall to increase the electrical power.

\section{Saving the Water at the End of the Rivers}

The mean annual water supply of Iraq is equal to $65.53 \mathrm{BCM}$ per year. However, the total average consumption of water is 54.17 BCM, (42.72 BCM per year for agricultural use, 9.7 BCM per year for industrial use, and $1.75 \mathrm{BCM}$ per year for domestic use). As a result, there is $11.36 \mathrm{BCM}$ per year is considered as a loss which goes to the Arabian Gulf without any use. This paper suggested constructing a dam north of Basra city to fulfil the following purposes:

A. To save the fresh water loss.

B. To separate the gulf salt water from the river fresh water to improve the drinking water quality.

This dam should include a spillway and also navigation lock.

\section{Conclusions}

The need for water resources is increasing as a result of population growth and economic development in Iraq. The following points are the main conclusions reached this study:

I. Mean annual water volume from the two Rivers and rainfall for 75 years is $65.53 \mathrm{BCM}$ per year and the average will be considered constant in the expectation.

II. Mean annual water volume from rainfall is 7 billion cubic meters per year for 75 years.

III. The population growth in Iraq is considered very high. It is about $2.31 \%$ as average. This rate should be reduced to $1.9 \%$.

IV. The average area used for agriculture is about 9.06 million ha, which is almost $79 \%$ of the cultivable area. In addition, the mean Arable land 
Citation: Abd-El-Mooty M, Kansoh R, Abdulhadi A (2016) Challenges of Water Resources in Iraq. Hydrol Current Res 7: 260. doi: 10.4172/21577587.1000260

Page 7 of 8

\begin{tabular}{|c|c|c|c|c|}
\hline Year & $\begin{array}{l}\text { Industrial water withdrawal }\left(10^{9}\right. \\
\left.\mathrm{m}^{3} / \text { year }\right)\end{array}$ & Total population & $\begin{array}{l}\text { Stake of one person per year } \\
\mathrm{m}^{3} / \mathrm{p} / \mathrm{year}\end{array}$ & $\begin{array}{l}\text { Industrial water withdrawal as \% of total } \\
\text { water withdrawal }\end{array}$ \\
\hline 1975 & 0.45 & 11684585 & 38.51 & 1.11 \\
\hline 1980 & 0.31 & 13653358 & 22.71 & 0.76 \\
\hline 1985 & 0.17 & 15576396 & 10.91 & 0.41 \\
\hline 1990 & 2.14 & 17478455 & 122.44 & 5 \\
\hline 1995 & 5.92 & 20217759 & 292.81 & 10.88 \\
\hline 2000 & 9.7 & 23574751 & 411.46 & 14.7 \\
\hline
\end{tabular}

Table 5: Industry water withdrawals for the period 1975 to 2000.

\begin{tabular}{|c|c|c|c|}
\hline Year & Population Growth (\%) & Population size & The stake of person per year (m $\mathbf{3}^{\mathbf{3}}$ \\
\hline 2015 & 2.89 & 35767000 & 1829 \\
\hline 2025 & 2.4 & 44351080 & 1475 \\
\hline 2035 & 1.92 & 52866487 & 1237 \\
\hline 2045 & 1.6 & 61325125 & 1067 \\
\hline 2065 & 1.45 & 70217269 & 932 \\
\hline 2075 & 1.95 & 83909636 & 780 \\
\hline 2085 & 2.45 & 104467497 & 626 \\
\hline 2095 & 2.95 & 135285408 & 484 \\
\hline 2100 & 3.2 & 178576738.8 & 366 \\
\hline
\end{tabular}

Table 6: The expectation of population and stake of the person in $\mathrm{m}^{3} / y$ ear for the period $2015 \mathrm{~s}$ to 2100 .

\begin{tabular}{|c|c|}
\hline Project name & Installed capacity(MW) \\
\hline Dokan Dam & 400 \\
\hline Darbandikhan Dam & 240 \\
\hline Mosul Main Dam & 750 \\
\hline Mosul Dam pump & 200 \\
\hline Mosul Regulating Dam & 60 \\
\hline Haditha Dam & 660 \\
\hline Samaraa Barrage & 80 \\
\hline Hemrin Dam & 50 \\
\hline Adhaim Dam & 40 \\
\hline Al-Hindiyah Barrage & 15 \\
\hline Shatt Al-Kuffa Regulator & 6 \\
\hline Total installed capacity & 2501 \\
\hline
\end{tabular}

Table 7: Installed hydropower capacity in Iraq [18].

area and permanent crops are about 5.05 million ha which represents $11.5 \%$ of total land and this percentage is very low.

V. The irrigated area by surface water is considered to be 2.84 million ha.

VI. The mean volume of water used in agriculture for the period 1975 to 2000 is 42.72 BCM per year, which represents $91.2 \%$ from the total water available. The agricultural water withdrawals per person as a mean are $2597.1 \mathrm{~m}^{3} /$ person/year for the same period.

VII. The mean water withdrawals for the municipal use are 1.75 BCM per year for the period 1975 to 2000 . However, the mean water withdrawal by one person for the period 1975 to 2000 equals to 91.77 $\mathrm{m}^{3} /$ person/year and as a result the water daily consumption for one person just for domestic use equals to 251.42 litres/person/day, these amount of water is considered high and should be reduced to maximum 150 litre/capita/day.

VIII. The used water for the industry in 2000 equals to $9.7 \mathrm{BCM}$ and it increased now due to the development of the country.

IX. In 2075 , the expected population will be 83.90 million, while the stake of person will be $780 \mathrm{~m}^{3} /$ person/ year.

$\mathrm{X}$. In 2100 , the population size is expected to be 178.5 million and the stake of one person will be $366 \mathrm{~m}^{3} /$ person/ year.

\section{Recommendations}

I. The water daily consumption for domestic use should be reduced to 150 litres/capita/day.

II. The water daily withdrawals for agricultural should be equals to 13 $\mathrm{m}^{3} /$ day/Donam. This meant that the water duty per hectare should be $52 \mathrm{~m}^{3} /$ day $\left(1\right.$ Donam $=2500 \mathrm{~m}^{2}, 1 \mathrm{ha}=10000 \mathrm{~m}^{2}, 1 \mathrm{ha}=4$ Donam $)$.

III. It is recommended to construct a dam with a lock in the north of Basra city south of Iraq on the Shatt al Arab River to control the water that goes to the Gulf as a loss. This will decrease the salinity in Shatt al Arab River and improve its water quality.

\section{List of Symbols}

BCM: Billion Cubic Meter.

b0: Intercept coefficient.

b1: Slope coefficient.

b2, b3: Parameters of the equation.

E: Discharges of Euphrates River.

F: Objective function.

n: Number of observations.

P: Numbers of predictor variables.

R: Rainfall volume.

TAWV: Total Annual Water Volume.

T: Discharges of Tigris River.

$\mathrm{X}$ : The horizontal axis.

Y: The vertical axis.

$\mathrm{x}$ : Predictor variables.

y: Creations variables. 
Citation: Abd-El-Mooty M, Kansoh R, Abdulhadi A (2016) Challenges of Water Resources in Iraq. Hydrol Current Res 7: 260. doi: 10.4172/21577587.1000260

\section{References}

1. Malinowski JC (2002) Iraq Geography: Military Academy. West Point, NY, Department of Geography and Environmental Engineering.

2. Al-Ansari NA, Ali AA, Knutsson S (2014) Present Conditions and Future Challenges of Water Resources Problems in Iraq. Journal of Water Resource and Protection 6: 1066-1098.

3. Crook J (2009) Climate Analysis and Long Range Forecasting of Dust Storms in Iraq. Master's Thesis, Naval Postgraduate School Monterey.

4. Food and Agriculture Organization of the United Nations (FAO) (2009) Geography, Climate and Population of Iraq.

5. MacQuarrie P (2003) Water Security in the Middle East, Growing Conflict Over Development in the Euphratestigris Basin. MPhil Thesis, International Peace Studies, Trinity College, Dublin, Ireland.

6. Al-Ansari NA (2013) Management of Water Resources in Iraq: Perspectives and Prognoses. Journal of scientific engineering researches 5: 667-684.

7. Issa IE, Al-Ansari NA, Sherwany G, Knutsson S (2014) Expected Future of Water Resources within Tigris-Euphrates Rivers Basin, Iraq. Journal of Water Resource and Protection 6: 421-432.

8. Bundesanstalt für Geowissenschaften, Rohstoffe BGR (2013) Inventory of Shared Water Resources in Western Asia. Chapter 3. Tigris River Basin. UN-ESCWA and BGR (United Nations Economic and Social Commission for Western Asia, Beirut).

9. Bundesanstalt für Geowissenschaften, Rohstoffe BGR (2013) Inventory of Shared Water Resources in Western Asia. Chapter 5. Shatt al Arab, Karkheh and Karun Rivers. UN-ESCWA and BGR (United Nations Economic and Social Commission for Western Asia, Beirut).
10. Bundesanstalt für Geowissenschaften, Rohstoffe BGR (2013) Inventory of Shared Water Resources in Western Asia. Chapter 2. Shared Tributaries of the Euphrates River. UN-ESCWA and BGR (United Nations Economic and Social Commission for Western Asia, Beirut).

11. Hussain HM, Al-Ansari NA, Knutsson S (2015) Groundwater Pollution Potential in Part of the Western Desert, Iraq. Journal of Earth Sciences and Geotechnical Engineering 5: 1-17.

12. World Bank (2006) Iraq Country water resource assistance strategy: Addressing Major Threats to People's Livelihoods. Washington DC, USA.

13. United Nations World Population Prospects (2012): The 2012 Revision, The Demographic Profile of Iraq.

14. FAO (2012) Investment centre. Iraq Agriculture sector note. Senior Economist Investment Centre Division.

15. Holli C (2010) Managing Iraq's Water Resources: The Path to Stability and Security. New Voices in Public Policy 5: 1-17.

16. Issa IE, Al-Ansari NA, Sherwany G, Knutsson S (2013) Trends and future challenges of water resources in the Tigris-Euphrates Rivers basin in Iraq Hydrology and Earth System Sciences Discussions. 10: 14617-14644.

17. Al Qatrani FS (2012) Environmental and Economic Impacts of Drought in Iraq Zeszyty Naukowe Uniwersytetu Szczecińskiego, Studia i Prace Wydziału Nauk Ekonomicznych i Zarządzania (29 Climate change, economy and societyinteractions in the Baltic See Region), pp: 5-17.

18. Taha A (2013) Renewable energy and hydropower utilization tendency worldwide. Renewable and Sustainable Energy Reviews 17: 213-215. 